\title{
Sorg før erindring
}

\section{9/11 mellem personligt traume og global begivenhed $i$ Art Spiegelmans In the Shadow of No Towers}

Det forekommer her godt syv år efter ikke længere nødvendigt at bemærke det umiddelbare chok, angrebet på World Trade Centers tvillingetårne afstedkom over det meste af kloden. Bemærkelsesværdige i dag er imidlertid reaktionerne på, hvad man kunne kalde vor tids Kennedy-mord eller, set med Vestkritiske briller, måske Vendôme-søjle - skønt disse begivenheder kun tåler sammenligning, hvad angår det symbolske element, idet de 3016 mennesker, der mistede livet den 11. september 2001, udgør et yderst konkret tab, de to andre begivenheder ikke på samme måde kan forbindes med. ${ }^{\mathrm{I}}$

Der gik ganske få timer efter tårnenes kollaps, før George W. Bush med sin texanske accent og med usynlig cowboyhat reducerede denne i mange henseender komplekse situation til en western-film, hvor de gode bekæmper de onde: "Make no mistake, the United States will hunt down and punish those responsible for these cowardly acts.”2 Og efter to uger var reaktionen den samme:

6f I see things this way: The people who did this act on America, and who may be planning further acts, are evil people. They don't represent an ideology, they don't represent a legitimate political group of people. They're flat evil. That's all they can think about, is evil. And as a nation of good folks, we're going to hunt them down, and we're going to find them, and we will bring them to justice. ${ }^{3}$

Hvorefter krigen mod terror og bekæmpelsen af "ondskabens akse" blev indledt med utallige flere ofre, militære såvel som civile.

De amerikanske myndigheders $\varnothing$ nske om at kunne demonstrere handlekraft synes at have afstedkommet en forceret og meget énstrenget begribelse af, hvad der egentlig skete, og hvilken betydning dette skete kunne have, nemlig at USA, og dermed demokratiet, var blevet angrebet af "det onde", og at dette onde måtte have Osama Bin Ladens ansigt, hvorfor denne forrykte galning på bedste cowboymanér skulle jages ind og skydes ned, således at retfærdigheden kunne ske fyldest, 
og normaltilstanden ville kunne genoprettes.

Det er denne forhippelse på så hurtigt efter begivenheden at ville lukke dens betydning, at etablere, hvad man med Ernesto Laclau og Chantal Mouffe kunne kalde en hegemonisk forståelse, ${ }^{4}$ hvis udspørgelse ville være uetisk, og som foreskriver, at vores "logiske" reaktion må være at indlede en "krig mod terror", der virker problematisk og i en sorg og erindringskulturel henseende yderst uhensigtsmæssig. Et andet sted, denne forhippelse på at komme videre uden at ville opholde sig ved det skete lader sig aflæse, er i den Memorial Competition på World Trade Center Site, der blev udskrevet næsten inden, at røgen fra de sammenstyrtede tårne havde lagt sig, dvs. inden man overhovedet havde gjort sig klart, hvad det var, der skulle erindres. ${ }^{5}$ Et af konkurrencens jurymedlemmer, den anerkendte mindesmærkespecialist James E. Young, der bl.a. også sad i juryen for konkurrencen om Denkmal für die ermordeten Juden Europas i Berlin, udtalte da også på et seminar på Wanås Slot $\mathrm{i}$ Skåne den 26. september i år, at han følte, at processen var blevet presset igennem, og at der ikke havde været nær nok tid til at sørge over tabet, før man ville rejse et mindesmærke. Young sammenlignede det med den jødiske sørgeskik, hvor der sørges et år, før den afdødes gravsten afsløres. I løbet af dette sorgår gennemleves en række rituelle stadier, begyndende med Shiva (den første uge) og shloshim (den første måned), der gradvist tillader de sørgende at bevæge sig fra sorgens til erindringens arbejde. Først når man har arbejdet sig gennem følelsen af tab, har fundet mening i den og har internaliseret erindringen om den afdøde, markerer man eksternt sorgen og tabet med en sten. ${ }^{6}$

David Foster Wallace påpeger i "Set fra Mrs. Thompsons stue" et vigtigt aspekt ved 9/11, som han kalder "Rædslen" (The Horror): "Noget, det er selvindlysende, men vigtigt at huske på i forbindelse med Bloomington og Rædslen er, at virkeligheden - oplevelsen af den større omverden - hovedsagelig er televisuel."” På grund af den massive globale mediedækning, hvor vi alle sad foran computeren eller tv-skærmen og fulgte live-transmissioner af de brændende tårne og følte, at vi var vidner til en afgørende historisk begivenhed, kan man spørge, hvad "9/11" egentlig er en betegnelse for: Refererer denne dato, som mange af os udtaler på amerikansk-engelsk, til en "symbolsk" global mediebegivenhed, vi alle var vidner til, ${ }^{8}$ eller til en mere konkret begivenhed, kun de, der befandt sig på Manhattan, var (øjen)vidner til?

Svaret er begge dele, skønt det mere personlige, mikropolitiske niveau synes at være blevet overskygget og i mange henseender tilsidesat af det overordnede makropolitiske. Det er netop denne manglende vilje til at forholde sig til det skete og bearbejde traumet og sorgen, Art Spiegelman problematiserer i In the Shadow of No Towers fra 2004.

Spiegelman forklarer i forordet, at han havde brug for at udrede "the fragments of what I'd experienced from the media images that threatened to engulf what I actually saw,"9 og påpeger på det første opslag, at "I live on the outskirts of Ground Zero and first saw it all live - unmediated." "I In the Shadow of No Towers, der i lighed med Spiegelmans berømte holocaust-værk, Maus fra 1986-91, er en såkaldt graphic novel, eller graphic narrative, ${ }_{\text {II }}$ er hans fors $\emptyset \mathrm{g}$ på at skabe en modfortælling, der genintroducerer traumet i en ny betydningsdannelse, hvor begivenheden ikke normaliseres og naturaliseres. 


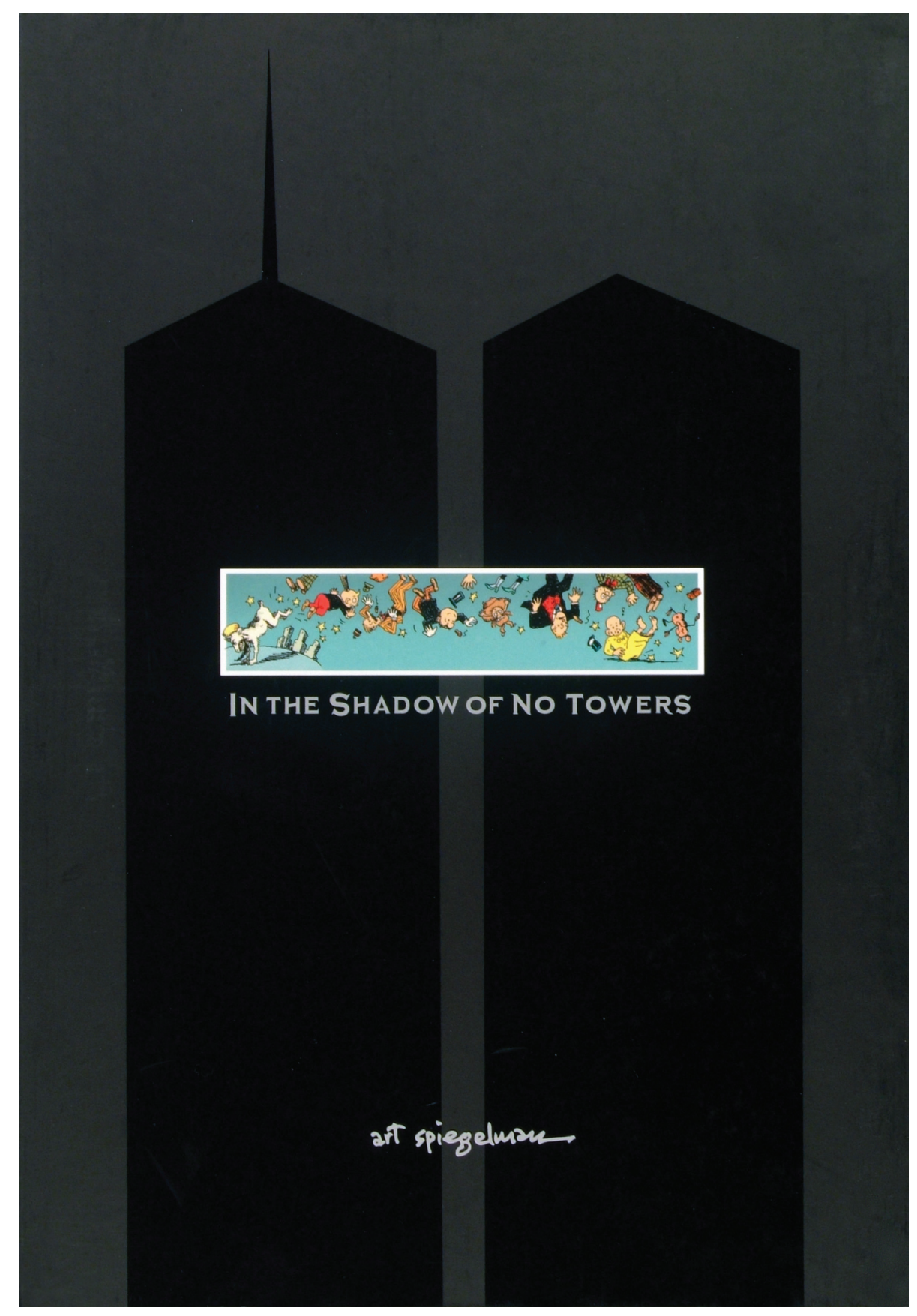


Hans personlige genfortælling af begivenhederne er præget af en vrede mod de politiske ledere, en vrede over at de "immediately instrumentalized the attack for their own agenda", reducerede det hele til "a war recruitment poster" og kastede USA ud i en kolonialistisk krig i Irak uden at gøre ret meget for faktisk at gøre USA til et sikrere sted at opholde sig, "beyond confiscating nail clippers at airports". ${ }^{\text {I2 }}$ Vreden udfoldes i store farvede vignetter, som ofte bryder ud af deres firkantede rammer, i lighed med de flammer som opløste tvillingetårnenes geometriske komposition. ${ }^{13}$ Spiegelmans uortodokse montage af forskellige tegneserie-stilarter antyder en rådvildhed eller et endnu ikke afsluttet forsøg på at forstå det tomrum, de to tårnes kollaps har efterladt.

In the Shadow of No Towers fremstår derfor i forhold til Maus påfaldende uafklaret, som om arbejdet med at begribe, hvad der skete, og hvordan dette skete skal repræsenteres, endnu ikke er færdigt. I dette arbejde benytter den sig eksplicit af Maus' repræsentation af holocaust og indfælder herved delvist 9/11 i de forståelses- og repræsentationsformer, der knytter sig til begribelsen af Auschwitz, fx når Spiegelman storrygende som sit Maus-alter ego erindrer sig sin fars forsøg på at beskrive, hvordan røgen i Auschwitz lugtede, og at faren ikke kunne komme nærmere end "ubeskrivelig", hvortil han efter en tankefuld pause udbryder: "That's exactly what the air in Lower Manhattan smelled like after Sept. 11!" ${ }^{\text {I4 }}$ Som David Hajdu skriver i sin anmeldelse af værket:

6 Spiegelman clearly sees Sept. 11 as his Holocaust (or the nearest thing his generation will have to personal experience with anything remotely correlative), and In the Shadow of No Towers makes explicit parallels between the events without diminishing the incomparable evil of the death camps. ${ }^{15}$

Men indfældelsen af 9/11 i den symbolske form, hvorigennem Spiegelman tidligere så succesfuldt lykkedes med at repræsentere sine forældres traumatiske erfaring af Auschwitz, er netop kun delvis og forsøgsvis. In the Shadow of No Towers er i modsætning til Maus ikke nogen fortløbende fortælling i grafisk form. Spiegelman, der ligesom i Maus optræder in propria persona i fortællingen og dermed også her fungerer som fortæller-person, har i stedet gengivet sine indtryk og oplevelser i ti farvelagte storskala $(24$ x 35,5 cm) opslag trykt på tykt karton, der hver især er uregelmæssigt opdelt i rammer eller paneler, og som oprindeligt blev publiceret som en føljeton i den tyske ugeavis Die Zeit, mens forsiden, det sort-på-sorte efterbillede af tårnene, oprindeligt blev bragt som forside af The New Yorker seks dage efter angrebet. Omkring halvdelen af materialet handler om, hvad Spiegelman og hans familie foretog sig den solbeskinnede tirsdag morgen. Materialet er frembragt gennem en overraskende mangfoldighed af stilarter og grafiske teknikker, fra hans sædvanlige kradserier, over mere maleriske billeder i bløde pasteller, til computerskanninger og approprierede figurer fra gamle avistegneserier (fx optræder Rudolph Dirks antiautoritære Katzenjammer Kids som tvillinger med hatte, der ligner de to World Trade Center-tårne, s. 2 og 4, Spiegelman selv optræder i skikkelse af den usofistikerede parvenu far fra Bringing up Father i en ægteskabelig diskussion om hans nyhedsforbrug, s. 8, ligesom Spiegelmans muse-alter ego fra Maus optræder sammen med 


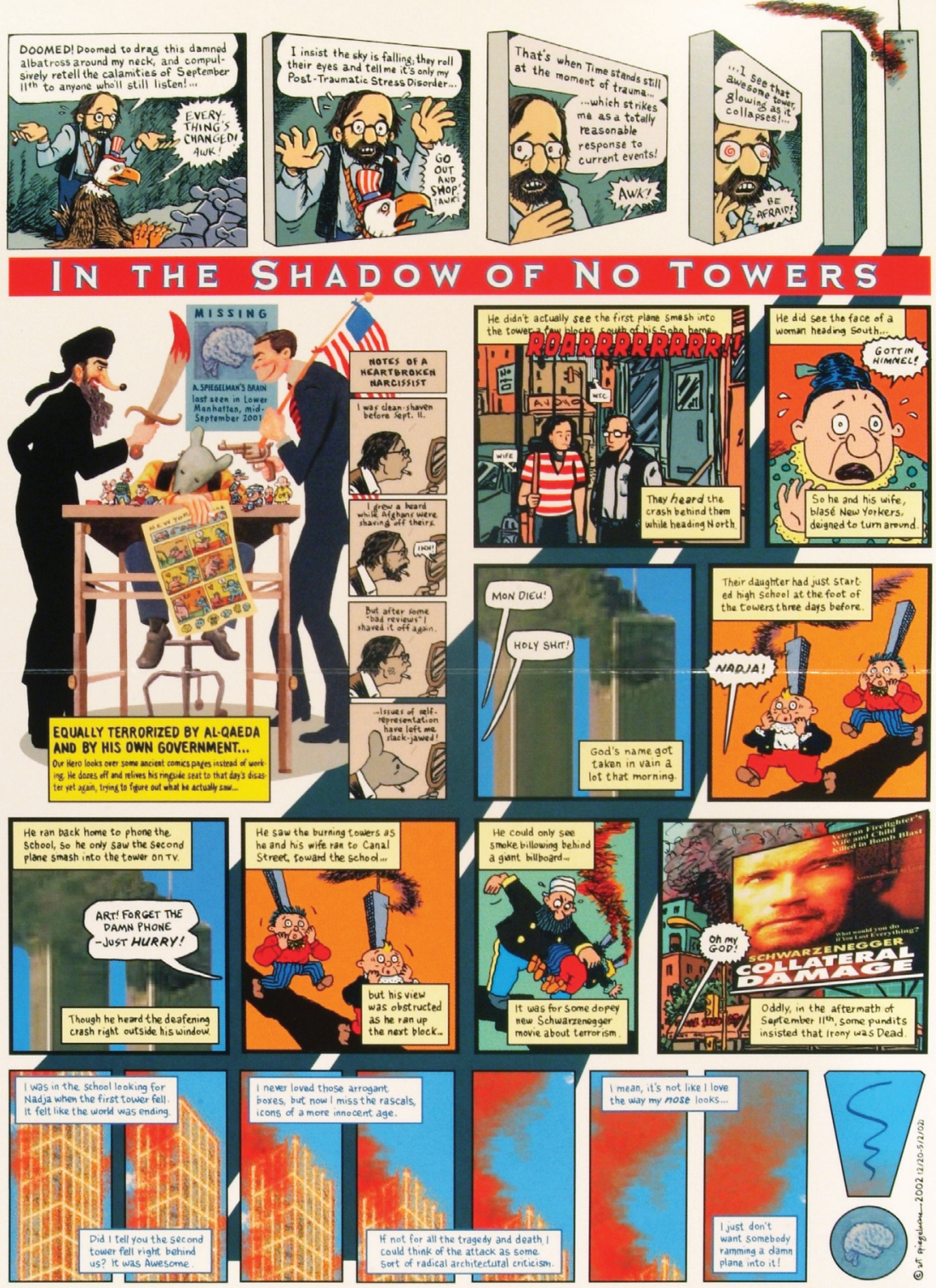

2 
musen Ignatz fra George Herrimans Krazy Kat, s. 8), ${ }^{16}$ hvor fem-seks historiesegmenter i hver sin grafiske stilart virker sammen i et om ikke kako- så polyfonisk og desorienterende udtryk; et af historiesegmenterne løber vertikalt, et i en stor cirkel, et er brudt op i spredte snapshot-lignende billeder etc. Den anden halvdel består af en uforsonlig satire over Bush-regeringens handlinger frem til den 31. august 2003. Opslagene efterfølger en tosides prosaintroduktion, "The Sky is Falling", hvori Spiegelman relativt detaljeret beskriver de omstændigheder, værket blev til under. Efter opslagene følger et tosides "Comic Supplement", der behandler avistegneseriens historie i USA, som illustreres med otte opslag med genoptryk af originale tegneseriestriber fra 1900-tallets begyndelse, blandt andre The Kin-der-Kids, Little Nemo og Bringing up Father.

Spiegelmans traumatiserende erfaring symboliseres gennem bogens centrale billede: "the image of the looming north tower's glowing bones just before it vaporized" ${ }^{17}$ Dette billede af det glødende tårn få sekunder før, det kollapser, optræder på alle opslagene og kommer derved til at tjene som et ledemotiv for bogen. Som sådan er det således nærliggende at betragte det som et vigtigt element i det, fortælleren selv diagnosticerer som sin post-traumatic stress disorder ${ }^{18}{ }^{8}$ Spiegelmans æstetiske sorgarbejde - brugen eller rettere genbrugen af the graphic novel eller tegneserien som medium (et medium der i parentes bemærket synes særligt velegnet til at fremstille Bush-regeringens kompleksitetsreducerende "krig mod terror" i) understreger afsøgningen af en adækvat form, en form der qua form nødvendigvis vil være æstetisk - peger på selve den proces, hvori den traumatiske begivenhed søges begrebet og integreret i det kulturelle, sociale, psykiske og politiske liv. In the Shadow of No Towers befinder sig midt i denne proces og insisterer på at opholde sig ved tabet og vedblive at bearbejde dette. Judith Butler hævder, at forholdet mellem sorg og sårbarhed er essentielt for forståelsen af de politiske reaktioner på tab, at en given sig hen til sorgen kan være en måde at forstå sårbarhedens mere omfattende politiske implikationer, og spørger: "If we stay with the sense of loss, are we left feeling only passive and powerless, as some might fear? Or are we, rather, returned to a sense of human vulnerability, to our collective responsibility for the physical lives of one another?"'19 I stedet for per instinkt at sætte jagten ind på Det Onde står Spiegelman ved sårbarheden og den sorg, han, newyorkerne, amerikanerne og hele det vestlige samfund er blevet påført. Freud bemærker som bekendt i sit essay om "Sorg og Melankoli", der blev skrevet og udgivet under Første Verdenskrig, at sorgen almindeligvis er "reaktionen på tabet af en elsket person eller af en abstraktion, som er trådt i dennes sted, såsom fædreland, frihed, et ideal osv.". ${ }^{20}$ Og dette sorgarbejde er, som også James E. Young antyder, uomgængeligt, hvis man vil undgå en potentielt skæbnesvanger fortrængning af tabet. ${ }^{2 \mathrm{I}}$

I forordet bemærker Spiegelman, at hans traumer før 11. september alle sammen havde været mere eller mindre selvpåførte, men at dette at have skullet løbe fra den giftsky, som World Trade Centers nordtårn forvandledes til, efterlod ham "reeling on that faultline where World History and Personal History collide". ${ }^{22}$ In the Shadow of No Towers er netop et udtryk for denne dobbelthed: at begivenheden for mange mennesker både var abstrakt politisk og uhyre konkret og reel, på én gang et personligt 


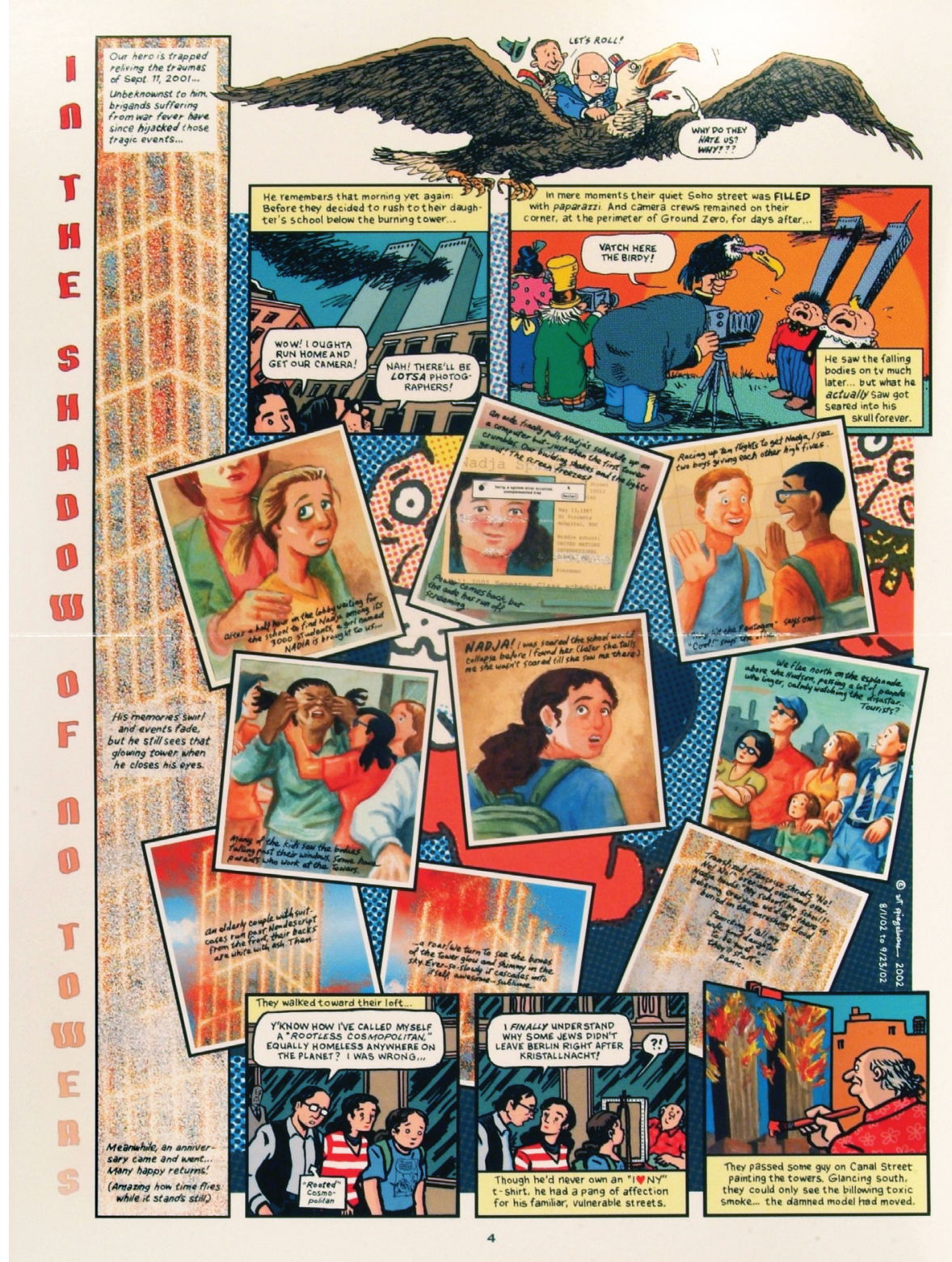


traume og en global begivenhed. Genbrugen af Maus-figuren antyder blandt andet, at han - det vil naturligvis sige fortællerprotagonisten Art Spiegelman - i In the Shadow of No Towers endnu ikke har fået integreret disse to dimensioner, den personlige fortælling og den kollektive historie, i en sammenhængende helhed. På trods af sammenligningerne fungerer Maus som udtryk for et relativt velbearbejdet traume, et traume som Spiegelmans forældre er blevet påført, men som er blevet videreført til postauschwitz-generationen, og som han har medvirket til at helbrede ved at lytte til og dernæst genfortælle sine forældres historie i en sammenhængende kunstnerisk form. ${ }^{23}$ I Maus forekommer det terapeutiske arbejde altså at være langt mere fremskredent - det tog ham efter eget udsagn 13 år at lave den - end i In the Shadow of No Towers, hvor det terapeutiske arbejde med traumet stadig synes at befinde sig i en tidlig fase.

Til forskel fra Maus, hvor Spiegelman fungerer som andethåndsvidne til sine forældres traumatiske erfaringer som ofre for Holocaust, og hvor fremstillingen foregår i en sammenhængende, omend eksperimenterende, især hvad angår grænser og konventioner for repræsentationen af Holocaust, form, hvori begivenhederne i en vis forstand har ladet sig indfælde, hvilket kun har kunnet lade sig gøre ved, at han har været i stand til at distancere sig fra dem, da har han ikke i In the Shadow of No Towers, hvor han altså i emfatisk grad har været førstehåndsvidne til den repræsenterede begivenhed, i samme udstrækning været i stand til at distancere sig fra begivenheden, som han - blandt andet på grund af det uudslettelige billede af det glødende tårn - stadig synes at være traumatiseret af, hvorfor han også er ude stand til at assimilere den og indfælde den i en sammenhængende narrativ form.

Det er især denne manglende evne til at begribe og formulere det skete, In the Shadow of No Towers er et vidnesbyrd om. Med andre ord kunne man sige, at mens Maus fremstår som et muligt vidnesbyrd om Holocaust, da fremstår In the Shadow of No Towers som et vidnesbyrd om, at det i 2004 endnu ikke var muligt at bære vidnesbyrd om 9/11 - at sorgarbejdet, selvom verden, da han begyndte at lave bogen, "seems to be ending more slowly than I once thought", ${ }^{24}$ endnu ikke var tilstrækkeligt gennemført til at kunne bevæge sig over i erindringsarbejdet, på trods af myndighedernes ihærdige bestræbelser på at få sorgen overstået og gennemtvinge igangsættelsen af et sådant.

\section{Noter}

I Nedstyrtningen af Vendôme-søjlen krævede ingen menneskeliv, men det gjorde naturligvis Versailles-troppernes nedkæmpning af kommunarderne under Den blodige uge i maj 1871.

2 http://english.peopledaily.com.cn/200109/12/eng20010912_79990.html [senest besøgt 4. oktober 2008].

3 http://www.whitehouse.gov/news/releases/2001/09/20010925-5.html [senest besøgt 4. oktober 2008].

4 Se hertil fx Ernesto Laclau \& Chantal Mouffe: "Hinsides det sociales positivitet: Antagonismer og hegemoni" ["Beyond the Positivity of the Social: Antagonisms and Hegemony", 1985], in idem: Det radikale demokrati - diskursteoriens politiske perspektiv, Roskilde: Roskilde Universitetsforlag, 2002, pp. 37-100. 
5 Forslag til udformning af mindesmærket skulle være indsendt senest den 30. juni 2003. Hele konkurrencematerialet findes på www.wtcsitememorial.org.

6 Den præmature igangsættelse af erindringsarbejdet kommer også til udtryk en række andre steder. Fx talte George W. Bush om hjælp til ofrene og afholdelse af et øjebliks stilhed allerede inden, at det tredje fly havde ramt jorden. Man appellerede til folk over hele verden om at afholde tre minutters stilhed kl. 11 om formiddagen fredagen efter begivenheden (dvs. den 14. september), mens redningsarbejdet i New York stadig var i fuld gang, og pårørende til ofrene stadig gik rundt fra hospital til hospital for at finde ud af, hvad der var sket, ligesom byen stadig var oversået med små efterlysningsnotitser, "Have you seen NN". Bush og mange andre vestlige ledere gik med andre ord direkte i gang med at mindes - samtidig med at de også med det samme begyndte at tale om genopbyggelsen af New York og af Verdens orden. Jf. Jenny Edkins: "The Absence of Meaning: Trauma and the Events of 11 September", in InfoInterventions, October 5, 2001, http://www.watsoninstitute.org/infopeace/911/index.cfm?id=4\# [senest besøgt 28. oktober 2008].

7 David Foster Wallaces tekst er oversat i nærværende nummer af Passage.

8 Eksempelvis Jürgen Habermas opfatter 9/11 som den første globale historiske begivenhed, idet den blev bevidnet globalt, enten mens den fandt sted eller med en minimal forsinkelse, jf. "Fundamentalism and Terror: A Dialogue with Jürgen Habermas", in Giovanna Borradori: Philosophy in a Time of Terror: Dialogues with Jürgen Habermas and Jacques Derrida, Chicago: University of Chicago Press, 2003, p. 28.

9 Art Spiegelman: "The Sky is Falling”, In the Shadow of No Towers, New York: Random House, 2004, upagineret.

Io In the Shadow of No Towers, p. 1.

II Hillary L. Chute og Marianne DeKoven har givet følgende beskrivelse af den grafiske fortællings karakteristika: "Graphic narrative, through its most basic composition in frames and gutters - in which it is able to gesture at the pacing and rhythm of reading and looking through the various structures of each individual page - calls a reader's attention visually and spatially to the act, process, and duration of interpretation. Graphic narrative does the work of narration at least in part through drawing - making the question of style legible - so it is a form that also always refuses a problematic transparency, through an explicit awareness of its own surfaces. Because of this foregrounding of the work of the hand, graphic narrative is an autographic form in which the mark of handwriting is an important part of the rich extra-semantic information a reader receives. And graphic narrative offers intricately layered narrative language - the language of comics - that comprises the verbal, the visual, and the way these two representational modes interact on a page." "Introduction: Graphic Narrative", in MFS Modern Fiction Studies, Volume 52, Number 4, Winter 2006, pp. 767-782: p. 767.

I2 In the Shadow of No Towers, "The Sky is Falling", upagineret.

I3 Jf. Devin Zuber: "Flânerie at Ground Zero: Aesthetic Countermemories in Lower Manhattan", in American Quarterly, Volume 58, Number 2, June 2006, pp. 269-299: p. 270.

I4 In the Shadow of No Towers, p. 3. En afgørende forskel i den visuelle repræsentation af de to begivenheder ligger i, at Holocaust i vid udstrækning har været omgærdet af et billedforbud, en usynlighed, mens vores opfattelse af 9/11 i høj grad er præget af billeder, af begivenhedens synlighed.

I5 David Hajdu: "In the Shadow of No Towers: Homeland Insecurity", in The New York Times Book Review, 12 September 2004, pp. 13-14: p. 13. 
I6 Jf. Katalin Orbán: “Trauma and Visuality: Art Spiegelman's Maus and In the Shadow of No Towers", in Representations 97, Winter 2007, pp. 57-89: p. 74, vedrørende disse referencer til nordamerikanske tegneserieklassikere.

I7 “The Sky is Falling”, upagineret.

I8 Jf. Kristiaan Versluys: "Art Spiegelman's In the Shadow of No Towers: 9/11 and the Representation of Trauma", in MFS Modern Fiction Studies, Volume 52 number 4, Winter 2006, pp. 980-1003: p. 993, der i den sammenhæng også henviser til Cathy Caruth, som definerer post-traumatic stress disorder, PTSD, som "a response [...] to an overwhelming event or events, which takes the form of repeated, intrusive hallucinations, dreams, thoughts or behaviors stemming from the event." Trauma: Explorations in Memory, Baltimore: Johns Hopkins UP, 1995, p. 4.

I9 Judith Butler: Precarious Life: The Powers of Mourning and Violence, London: Verso, 2003, p. 30. Jf. også Marita Sturken: "From Kitsch to Irony: The Aesthetics of American Memorial Culture", in Elna Svenle \& Marika Wachtmeister, red.: Förlust/Loss, udstillingskatalog, Wanås, Sverige, 2008: pp. 33-45: p. 44.

20 Sigmund Freud: "Sorg og melankoli" ["Trauer und Melancholie”, 1915, udgivet 1917], in idem: Metapsykologi bd. 1, København: Hans Reitzels Forlag, 1972, pp. 219-239: p. 223.

2I Se også Mikkel Bolts artikel "Spektakulær krig" i nærværende nummer af Passage vedrørende den amerikanske regerings eftersøgning af et billede, der kan tilintetgøre 9/11 og genskabe verden.

22 "The Sky is Falling", upagineret.

23 Vedrørende postauschwitz-generationens repræsentationer af Holocaust se min artikel "At give erindringen form: Om repræsentationen af Auschwitz", in Passage 58, 2007, pp. 39-52.

24 "The Sky is Falling", upagineret. 